\title{
構造目地を有する鉄筋コンクリート造腰壁付き骨組の 力学的特性に関する研究
}

その III 一腰壁付き柱の最大荷重の決定過程と腰壁の反力挙動

\section{A STUDY ON CHARACTERISTIC OF REINFORCED CONCRETE SPANDRELS- BEAMS-COLUMNS TYPED FRAMES WITH THE STRUCTURAL SLITS}

Part III Reaction behavior of spandrels against column deformation

\author{
塩屋 晋一* \\ Shin-ich SHIOYA
}

\begin{abstract}
This paper focusses seismic behavior of reinforced concrete columns with a gap, called the "Structural Slits" in this paper. The purpose to provite the Structural Slits is to mitigate the undesirable effects of spandrels on reinforced concrete frames, such as shear failure of columns during an earthquake.

The reaction condition of a spandrel in the maximum lateral load of a column $Q_{S L U}$ caused by the crush of concrete at Structural Slits is cleared up by the analysis of a test results and the fi-
\end{abstract} nite element analysis.

Keywords : reinforced concrete, structural slit, spandrel column, maximum load, reaction of spandrel, finite element analysis

鉄筋コンクリート, 構造目地, 腰壁付き柱, 最大荷重, 腰壁の反力, 有限要素解析

\section{1. 序}

本研究は，鉄筋コンクリート造腰壁付き骨組において 柱と腰壁の境界に壁厚を局部的に薄くさせる久損（構造 目地）を設け，地震時にこの壁部分（目地部）を破壊（目 地破壊）させることにより，腰壁の悪影響”を回避する ことを目標とした設計法に関する一連の研究2).37である。

腰壁は柱の両側または片側に設けられ, 柱の水平挙動 を拘束する。ここでは柱に対し，圧縮抵抗する壁を圧縮 側腰壁, 引張抵抗する壁を引張側腰壁とする。特に問題 になる壁は, 圧縮側腰壁である。引張側腰壁は, 柱との 境界に低い荷重レベルで引張ひび割れが発生し，これ以 降，柱をほとんど拘束しない。本章の以下では圧縮側腰 壁について論じている。

構造目地を設けて梁降伏形の骨組を形成させるための 設計法として，基本的につぎのこど目標にする。

中・上層では，柱を破壊させず梁端を曲げ降伏させる ことから, 目地部は主に梁の曲げモーメントにより破壊 され，目地破壊が腰壁下端まで進展した後に梁下端主筋 を引張降伏させ曲げ降伏させる。これにより梁の曲げ耐 力や柱への入力せん断力などの増加を抑制する。それに
対し最下層では, 基礎梁の断面を柱に対して大きくし柱 脚を曲げ降伏させることから, 目地部は主に柱の変形に よってて破壊され, 目地破壊が腰壁下端まで進展した後に 柱脚を曲げ降伏させる。これにより, 柱への入力せん断 力の増加や短柱化による柱のじん性の劣化などを抑制す る。前々報 ${ }^{2}$, 前報 ${ }^{3}$ では中・上層を対象に構造目地を 設けた腰壁付き, 骨組の力学的特性や梁の曲げ強度式な どについて述べた。本論文では最下層を対象にする。

筆者は最下層を対象にした構造目地を設けた腰壁付き 柱の加力実験を行っている4)。これによる柱の水平荷 重・層間水平変形の関係. (以後, 荷重 - 変形関係) の特 徵を図一1に示す。構造目地の設置により,じん性に乏 しい柱の曲げ破壊やせん断破壊は回避されるとともに, 目地破壊に伴って剛性低下や荷重低下が生じる。最大水 平荷重は, 目地破壊の進展, または目地破壊の進展後の 柱脚の曲げ降伏 (降伏機構形成这1) によって決定される。 本研究では, 目地破壊の進展に伴って荷重低下が生じう るときの柱のせん断力を目地強度, 曲代降伏機構が形成

注 1) 実験では柱頭・柱脚降伏形であるが, 梁降伏形の骨組 では上梁端と柱脚が曲げ降伏し，機構が形成される。

* 九州芸術工科大学 助手・修士 (工学) Research Assoc., Kyushu Institute of Design, M. Eng. 


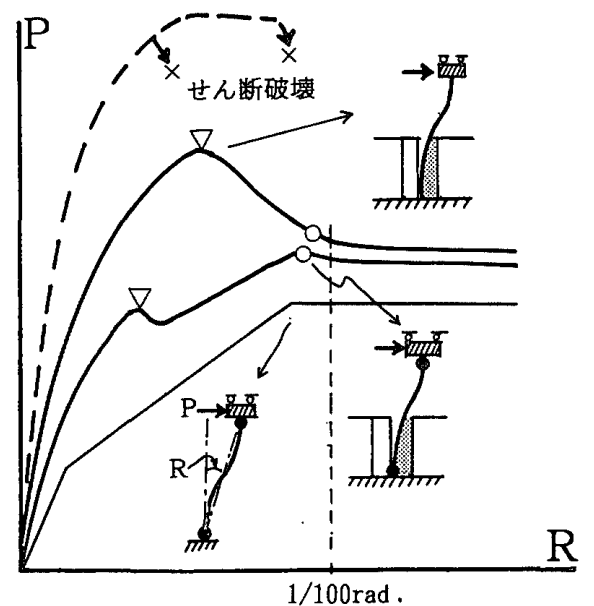

$(\nabla$ :目地強度、○：降伏強度、降伏ヒンジ)

図一1 荷重変形関係の特徵

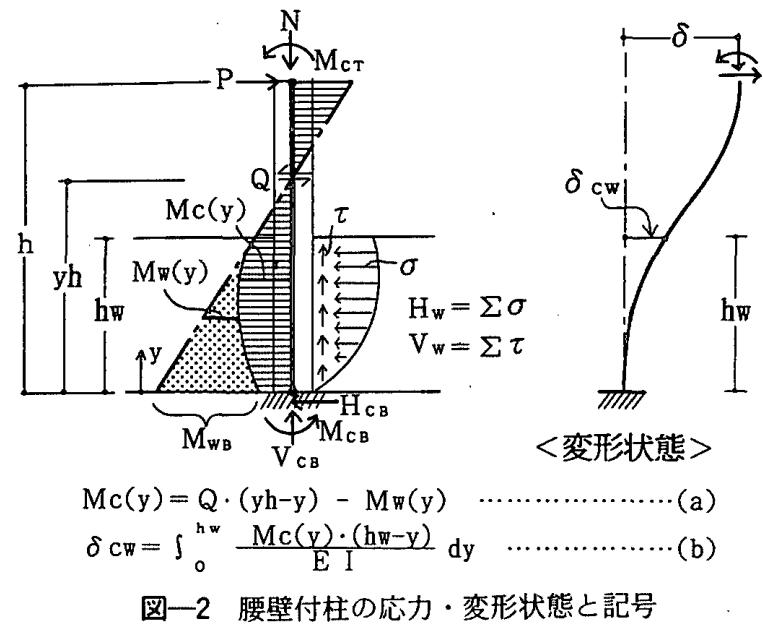

されたときの柱のせん断力を降伏強度とする。目地破壊 が腰壁下端近傍まで進展した後に柱脚が曲げ降伏するよ うに柱が設計されていると, 最大荷重はこれらの強度の うち大きい強度に等しく, 設計の際, それぞれの強度と 柱の曲げモーメント分布の評価方法が必要になる。

強度式は, 各強度時の腰壁付き柱の応力・変形状態が ある程度明らかであれば, 誘導される。降伏強度時につ いては，実験の破壊状況から「目地破壊が腰壁下端近傍 まで進展しているとともに曲げ降伏機構が形成され，柱 の変形角が $1 / 100 \mathrm{rad}$. 程度である41」と定義できるが, 目地強度時については，柱は破壊せず一定の剛性を有し ていることもあり，破壊状況のみからは定義できない。

図一 2 に水平荷重・軸力・モーメントが柱頭に作用す るときの腰壁付き柱の曲げモーメント・反力状態を示 す。柱脚部分が腰壁と基礎梁に支持されていると考えれ ば，その支持部で生じる力は反力となる。図中の は柱に生じる曲げモーメントで, -ーーは柱断面中心線 上での各高さ位置に関する外力 $\left(P, N, M_{C r}\right)$ によるモー メントである。これらの外力によるモーメントに対し腰 壁付き柱は, 柱頭から腰壁上端までは柱のみで, 腰壁上
端から柱脚までは腰壁と柱でそれぞれ抵抗する。ドット の部分は, 腰壁の反力によるモーメントに相当し, 腰壁 が負担するモーメントを意味する。ここでは，腰壁が各 高さ位置で負担するモーメントを腰壁の負担モーメン ト，その分布を腰壁の負担モーメント分布と定義する。

平石・川島らうは目地部のひずみ分布形状を一義的に 仮定して算出される腰壁の水平反力 $H_{W}$ が最大となった ときを目地耐力時とし，このときの柱の水平荷重とその $H_{W}$ が等しい, として耐力式を提案している。しかし, そこでは柱の荷重・変形関係で目地耐力が持つ力学的意 味や, $H_{w}$ と柱の水平荷重の関係, 柱の曲げモーメント 分布などについては検討がなされていない。

本研究では, 目地破壊に伴う荷重低下と腰壁の反力挙 動の関係や，目地強度時の腰壁の負担モーメント分布 $M_{w}(y)$ と腰壁高さ位置の柱の水平変位 $\delta_{C w}$ を明らかに し，目地強度式をつぎのように誘導する。

目地強度時の腰壁付き柱の応力・変形状態に関する記 号を図一2のものとすると，腰壁と接する柱の曲げモ一 メント分布 $M_{c}(\mathrm{y})$ は図中の（a）式で表せる。そして， 柱のせん断変形を無視し, 柱の曲げ剛性を $E I$ とすると, $\delta_{c w}$ は (b) 式で表せる。 $M_{w}(\mathrm{y})$ と $\delta_{c w}$ が $Q$ の関係式で 与えられれば，(a) 式を（b) 式に代入し，Qについて 整理すると, 目地強度式は誘導される。以下に $y h$ が既 知の場合の目地強度略算式を示す。

$$
Q=\frac{\left(A_{i} \cdot s_{L} \varepsilon_{B} \cdot d s+\delta_{w}\right) E I / h_{w}^{2}+B_{i} \cdot m}{\left(C_{i}+D_{i} \cdot s_{L} \varepsilon_{B} \cdot d s \cdot E I / h_{w}^{2} \cdot m\right) y h+E_{i} \cdot h_{w}}
$$

ここに, $A_{i} \sim E_{i}$; 目地部の王縮特性夕イプによって決ま る定数

$$
{ }_{s L} \varepsilon_{B}, d s, \delta_{w}, m ; \text { 図-12 参照 }
$$

本論文では，2章で構造目地を設けた腰壁付き柱の水 平加力実験結果 ${ }^{4)}$ を述べ，この結果を基に 3 章で目地破 壊に伴う荷重低下と腰壁の反力挙動の関係について考察 をする。4 章では, 弾・塑性有限要素解析による検討を 加え, 目地強度時の, 腰壁の負担モーメント分布と水平 荷重の関係, $\delta_{C W}$ に関する目地部のひずみと水平荷重の 関係を示す。なお目地強度と降伏強度の具体的な強度式 については，次報（P art IV）で報告する予定である。

\section{2. 搆造目地を有する腰壁付き柱の水平加力実験 ${ }^{4)}$}

実験の計画・結果の詳細については, 文献 4）に記し てあるので, 本章では実験概要と次章以降での考察に必 要な実験結果について述べる。

\section{1 実験概要}

図一 3 に試験体の基本形状と加力装置を，表一 1 と表 一2に試験体の諸元と材料特性を，それぞれ示す。図一 3 のハッチの部分に矩形目地を設けている。図一4 と表 一3に試験体に設けた矩形目地の圧縮実験結果を示して いる。加力については, 柱頭と柱脚の回転角（図一3の 


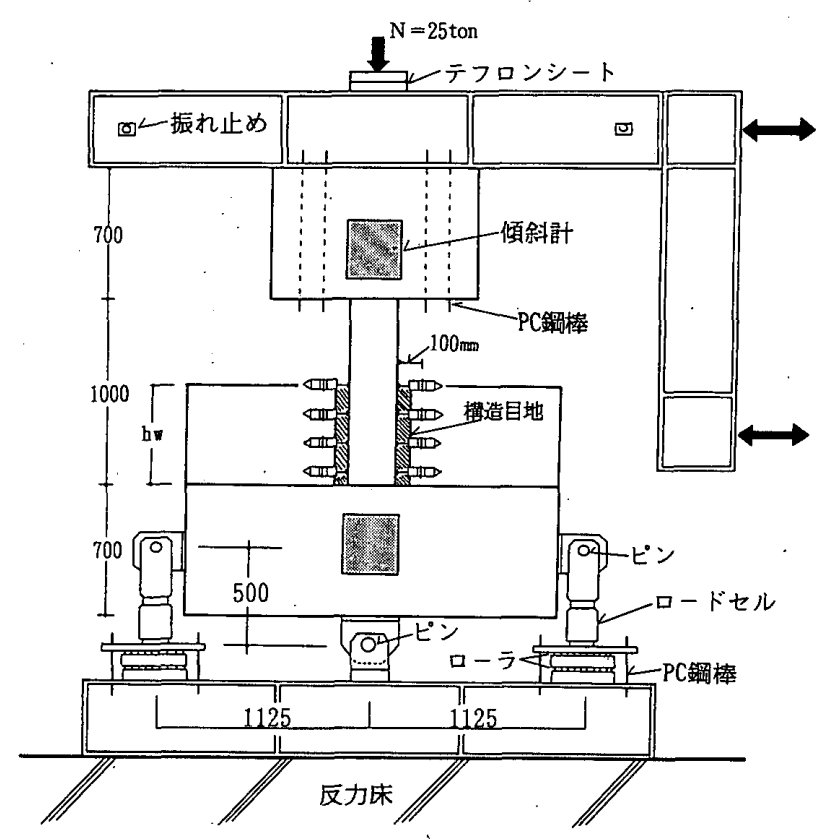

図一3 試験体と加力装置

表一1 試験体一覧亡諸元値

\begin{tabular}{|c|c|c|c|c|c|c|}
\hline No. & 試匰体 & 目地部の、 & 法 (cm & ）目垉費急 & 壁高 & 柱 \\
\hline & 名称 & $\mathrm{ts}^{+}, \mathrm{ts}^{-}$ & $\mathrm{w}$ & 樜跭量 & (c⿴囗十) & \\
\hline & $\operatorname{cs} 35-1$ & 1.5 & 4.5 & $4-4 \phi^{i \neq}$ & 35 & 断面 \\
\hline 2 & CS55-1. & 2.0 & 4.5 & $6-4 \phi^{*}$ & 55 & $25 \times 25 \mathrm{~cm}$ \\
\hline 3 & $\operatorname{cs} 35-2$ & 2. 1 & 4.0 & & & 哺強筋 \\
\hline 4 & $\operatorname{cs} 35-2$ & 2.7 & 5.0 & & 35 & 3-D13 \\
\hline 5 & $\operatorname{cs} 35-3$ & 3.7 & 7.0 & 無し & & $\mathrm{Pt}=0.61 \mathrm{x}$ \\
\hline 6 & $\operatorname{cs} 45-2$. & 2.6 & 5.0 & & 45 & 8-D13 \\
\hline 7 & $\operatorname{cs} 55-2$. & 2.1 & 4.0 & & & $=1.63 x$ \\
\hline 8 & $\operatorname{cs5} 5-2$. & 2.5 & 5.0 & & 55 & $P_{W}=0.519$ \\
\hline
\end{tabular}

注） $\mathrm{ts}^{+}$; 正加力時に圧溒する目地部の壁厚

$\mathrm{ts}^{-}$; 負加力時に圧壊する目地部の壁厚

目地貫通横筋は、ts ${ }^{-}$側の目地のみに配筋

表一2 使用材料の力学的特性

\begin{tabular}{|c|c|c|c|c|c|}
\hline \multirow{4}{*}{$\begin{array}{r}\text { בンク } \\
\text { リート } \\
\end{array}$} & 試鈳体 & $c=c \sigma_{B}$ & $c \mathcal{E}_{\text {B }}$ & $\underset{\left(\mathrm{kg} / \mathrm{cm}^{2}\right)}{\mathrm{Ec}}$ & $\begin{array}{c}\mathrm{Fsp} \\
\left(\mathrm{kg} / \mathrm{cm}^{2}\right)\end{array}$ \\
\hline & No. 1,2 & 266 & 0.253 & $2.21 \times 10^{5}$ & 19.8 \\
\hline & No. 3 5 & 239 & 0.282 & $2.15 \times 10^{5}$ & 20.7 \\
\hline & No. $6 \sim 8$ & 265 & 0.270 & $2.21 \times 10^{5}$ & 24.6 \\
\hline \multirow{6}{*}{ 鉄 筋 } & $\begin{array}{l}\text { 鉄筋 } \\
\text { の種類 }\end{array}$ & $\begin{array}{l}\text { 試験体 } \\
\text { 番号. }\end{array}$ & $\begin{array}{c}\sigma \mathrm{y} \\
\left(\mathrm{kg} / \mathrm{cm}^{2}\right)\end{array}$ & $\begin{array}{c}\sigma_{\mathrm{B}} \\
\left(\mathrm{kg} / \mathrm{cm}^{2}\right)\end{array}$ & $\begin{array}{c}\text { Es } \\
\left(\mathrm{kg} / \mathrm{cm}^{2}\right)\end{array}$ \\
\hline & $4 \phi$ & \multirow{3}{*}{ No. $1 \sim 8$} & 3680 & 3820 & $1.79 \times 10^{6}$ \\
\hline & D6 & & 3630 & 5490 & $1.68 \times 10^{6}$ \\
\hline & D16 & & & & $.82 \times 10^{6}$ \\
\hline & D13 & $\mathbf{N}$ & 3920 & 5942 & $1.77 \times 10^{6}$ \\
\hline & D13 & No. 3 8 & .3670 & 5372 & $1.75 \times 10^{6}$ \\
\hline
\end{tabular}

傾斜計）が等しくなるように上下の水平加力差で制御祀 しながら正負の繰返し水平加力（柱層間変形角 $R= \pm$ $1 / 100, \pm 1 / 50 \mathrm{rad} . の 2$ cycle) を行っている。柱主筋 ひずみをひずみゲージで,・目地部を含む腰壁之柱の間の 相対水平変形 (区間 : $100 \mathrm{~mm}$ ) を変位計でそれぞれ測 定している。

注 2）基礎梁の変形や基礎梁を固定する治具に生ずる変形に より柱脚には回転が生じる。実験結果の解析を容易に するために柱脚と柱頭の回転角に一定の規則を与え た。
表一3 目地部の圧縮実験結果

\begin{tabular}{|c|c|c|c|c|c|c|c|}
\hline $\begin{array}{l}\text { 対応する } \\
\text { 試験体番号 }\end{array}$ & \multicolumn{2}{|c|}{ No. 1 , No. 2} & No. & No. 4 & No. 5 & $\begin{array}{l}\text { No. } 6 \\
\text { No. } 8 \\
\end{array}$ & No. 7 \\
\hline ts $(\mathrm{cm})$ & 1.6 & 2. & 2. & 2.6 & 3.6 & & \\
\hline (c⿴囗十) & 4.5 & 4.5 & 4. & 5.0 & 7.0 & 5. & 4. \\
\hline $\mathrm{L} \sigma_{\mathrm{B}}\left(\mathrm{kg} / \mathrm{cm}^{2}\right)$ & 261 & 300 & 27 & 244 & 258 & 281 & 299 \\
\hline$\delta_{\mathrm{B}}(\mathbb{m} \mathbb{I})$ & .28 & .31 & .31 & 31 & .39 & 3 & 30 \\
\hline & & & & & & & \\
\hline
\end{tabular}

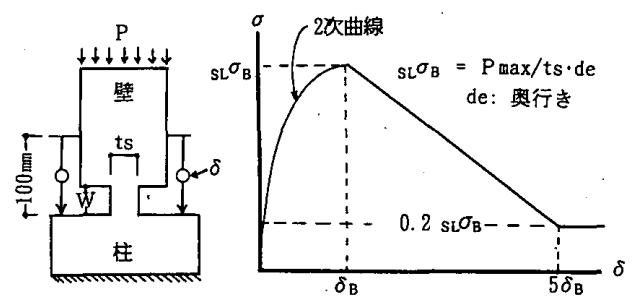

図一4·目地部の圧縮特性

\section{2 実験結果概要}

図一5に正加力時の柱の荷重・変形関係（包絡線）の 例を実線で示す。図中に柱主筋の降伏状況，目地部（圧 縮側腰壁）の圧壊進展範囲，ひび割れ状況の例を示す。

No. 2 と No. 3 は目地部が比較的小さい荷重レベルで 破壊し柱頭・柱脚の曲げ降伏により最大荷重が決定して いる。No. 5 No. 8 は目地部の圧壊の進展により最大荷 重が決定している。全武験体とも目地部の圧壊が腰壁下 端近傍まで進展した後に曲げ降伏機構が形成されてい た。腰壁の破壊については，図中の No.3，No.8 と同 様に全試験体とも，圧縮側腰壁では目地部だけが圧壊し， 引張側腰壁では目地部と柱の境界に添って生じた縦ひび 割机が発生・拡大していた。以降特記しない限り目地破 壊は, 目地部の圧壊を意味する。

\section{3 目地部の水平ひずみ分布形状}

図一6に目地部の水平方向のひずみ分布形状を目地壁 厚 $t_{s}$ (図一4) が変化する場合と腰壁高さ $h_{w}$ が変化する 場合について示す。この分布は，纴縮側腰壁で変位計に より測定された水平変形を基にひずみを算出し，腰壁上 端の圧縮ひずみで無次元化している。○○口は目地部が 圧壊開始した時点，人口は圧壊が約 $0.5 h_{w}$ の高さ位 置まで進展した時点の分布である。

目地強度時の分布は，白塗り（○など）と黒塗り なビ）の中間の分布に相当し，目地強度前後のひずみ分 布形状は目地破壊の進展に伴い徐々に緩やかな分布に変 化している。

図中の破線の分布は, 柱の曲げモーメント分布を図一 7 に示す 3 種類に仮定したときの柱の曲げ変形分布であ る。ただし，柱の曲げ剛性は一定としている。柱の曲げ モーメント分布と変形分布形状は， $t_{s}$ や $h_{w}$ が小さく なったり, 目地破壊が進展したりすると腰壁の反力が減 少するため, . (c) $\rightarrow(\mathrm{b}) \rightarrow(\mathrm{a})$ の状態へ推移することに なる。また， $t_{s}$ が小さくなったり，目地破壊が進展す 

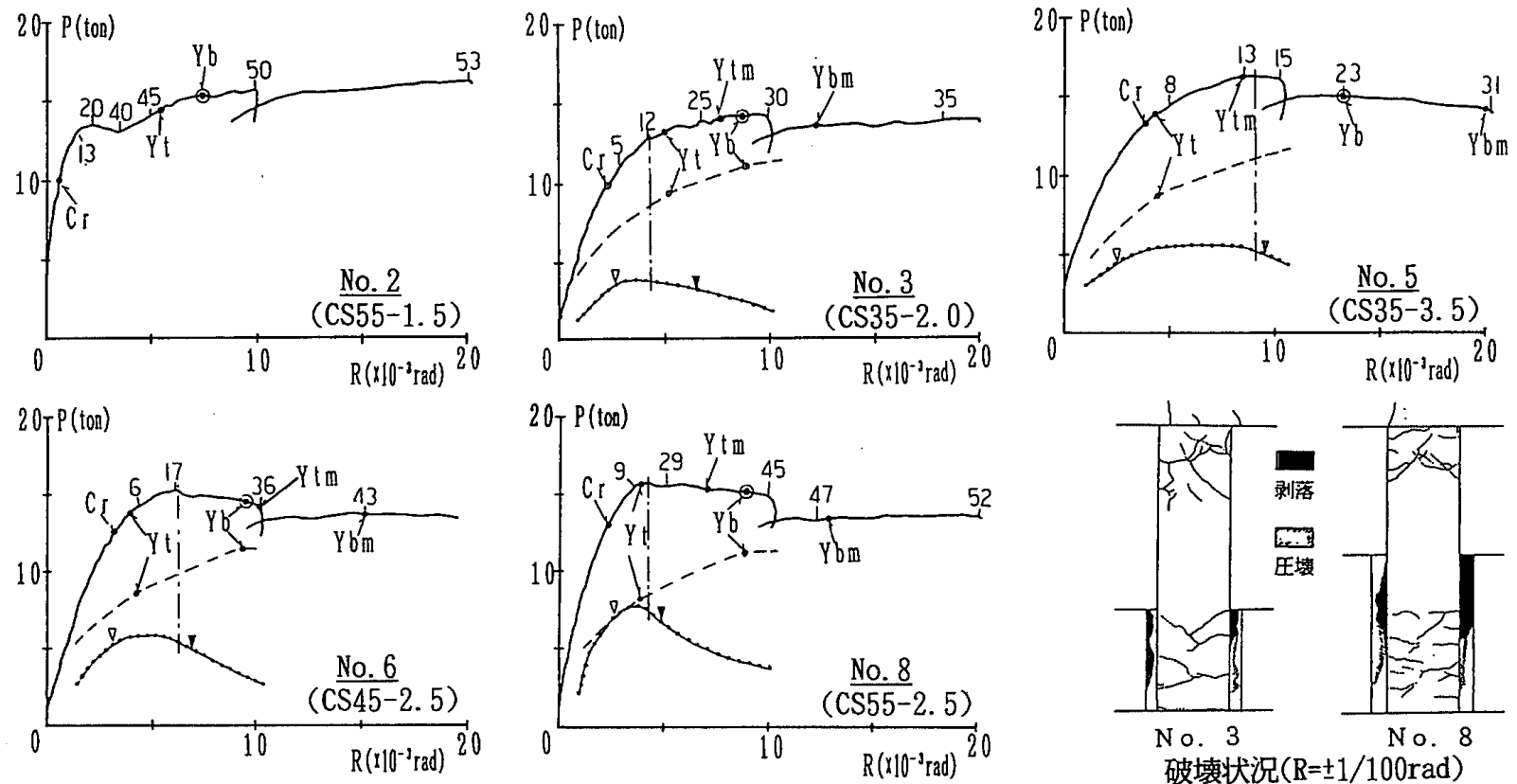

CS35-1.5 C r : 目地厈壊開始 $\mathrm{Yt}$ : 柱頭引張鉄筋降伏 $\mathrm{h}_{\mathrm{w}} \mathrm{J} \mathrm{L}_{\mathrm{ts}} \mathrm{Yb}$ : 柱脚引張鉄筋降伏 $\mathrm{Ybm}$ : 柱脚中間鉄筋降伏

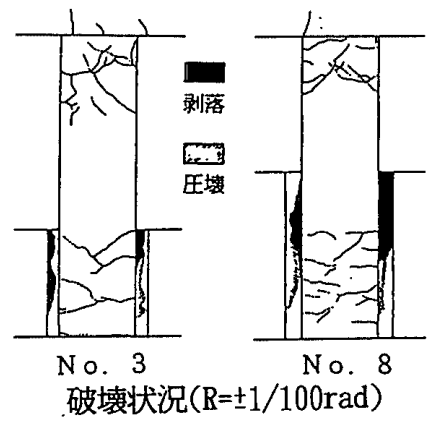

$\mathrm{Ytm}$ : 柱頭中間鉄筋降伏

数値 : 压縮側腰壁での壬壊範囲 $(\mathrm{cm})$

图一5柱の水平荷重・層間変形関係（正側包絡線）

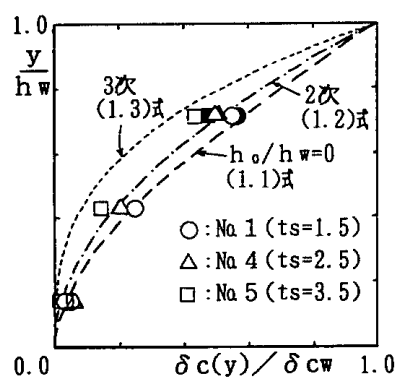

(a) tsが変化する場合

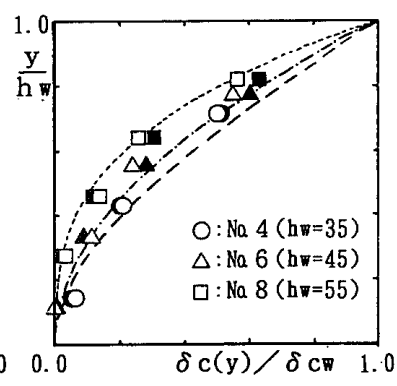

(b) h㽖变化する場合

図一6目地部の水平ひずみ分布形状

ると柱の水平変位に対し目地部の水平圧縮変形の占める 割合が大きくなる4)ため，目地部のひずみ分布形状も， 柱の変形分布形状とほぼ同様に推移するものと考えられ る。この傾向は, 図一6において $t_{s}, h_{w}$ が比較的大き い試験体（No.5，No.8）ほぼ 3 次分布に近くなってい ることで確認できる。

\section{4 腰壁の負担モーメント分布}

図一8に最大荷重時の, 柱の曲げモーメントと外力に よるモーメントをNo.5, No.8についてそれぞれ示す。 図中のー。一は柱の曲げモーメント，ー-ーは外力による モーメントである。柱の曲げモーメントは付録 1 の算出 方法により，外力によるモーメントは水平荷重（図一3） との釣合いより，それぞれ求めている。目地部で王壊が 生じた以降で両者を比較すると, 付録 1 による柱頭・腰 壁上端位置の柱の曲げモーメントは，外力によるモーメ ントを約 $\pm 7 \%$ 以内の誤差で推定していた。また他の試 験体も同程度の誤差で推定されていた。図中のドットの 部分が腰壁の負担モーメント分布に相当する。柱脚位置
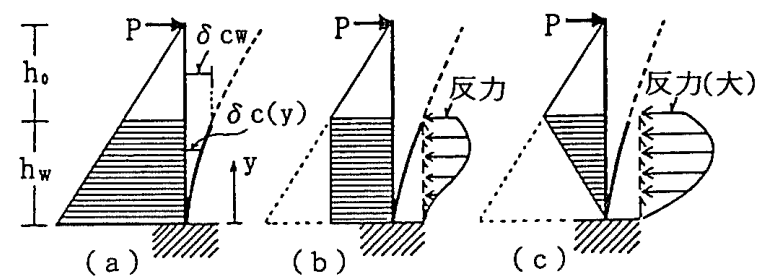
(a) ; $\delta \mathrm{c}(\mathrm{y}) / \delta \mathrm{cm}=(\mathrm{y} / \mathrm{hm})^{2}\left(1+\frac{\mathrm{hw}-\mathrm{y}}{3 \mathrm{ho}+2 \mathrm{hw}}\right)$
(1.1)
(b) ; $\delta \mathrm{c}(\mathrm{y}) / \delta \mathrm{ct}=(\mathrm{y} / \mathrm{ht})^{2}$
(c) $; \delta \mathrm{c}(\mathrm{y}) / \delta \mathrm{cw}=(\mathrm{y} / \mathrm{hw})^{3}$
(1.3)

図一7柱の曲げモーメントと水平変形分布

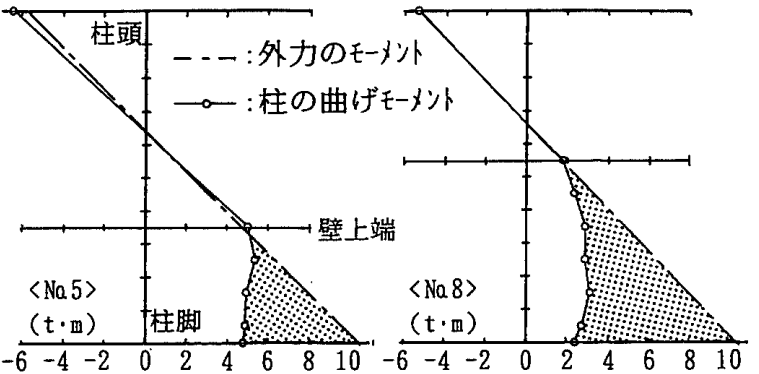

図一8 柱の曲げモーメントと外力によるモーメント

の負担モーメントを $M_{W_{B}}$ とし $M_{W_{B}} / h-\delta$ 関係を図一 5 に一正ず示す $h$ は柱長さ(単位長さ) である。 $M_{w B}$ は 王縮側腰壁の反力によるモーメントであるため, 目地破 壊の進展に伴い最大值に達している。図一 9 に $M_{w B}$ が最 大となる前後の時点（図一 5 の,$\nabla)$ の $M_{w}(y)$ の分布 形状を $M_{W B}$ で除して示す。分布形状は, 目地破壊の進 展に伴って腰壁の反力の合力重心位置が腰壁下端方向に 移動するため直線的な形状から曲線的な形状に変化する 


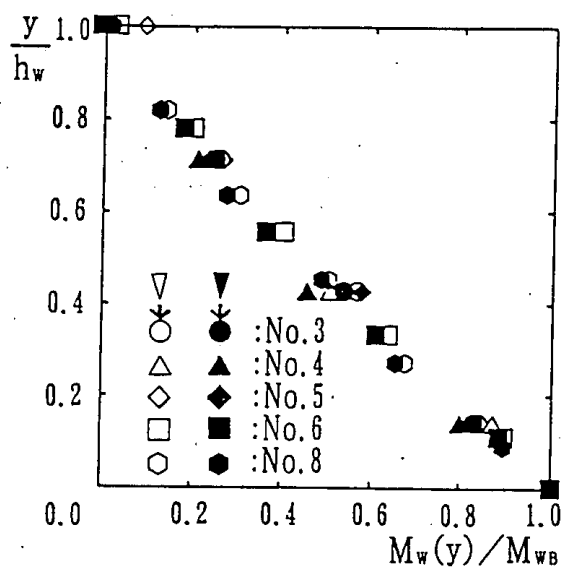

图一9 目地強度前後の $M_{w}(y) / M_{W B}$

傾向が若干みられる。

\section{3. 荷重低下と腰壁の反力挙動}

荷重・変形関係では目地破壊の進展に伴い, 剛性低下 や荷重低下などが生じる。最大荷重の直後を含む荷重低 下の発生は, 㔄性低下の程度に左右される。

この章では, 目地破壊の進展に伴う荷重低下と腰壁の 反力挙動の関係について考察する。

\section{1 剛性低下}

水平荷重 $P$ を受ける腰壁付柱の応力・変形は, 各荷 重ステップの柱の瞬間剛性に基づいて重ね合わせの原 理付䤸 2 にり，図一10のように 3 種類の応力・変形成分 に分解して考えられる。同図の (c)，(d) から明らか なように, 増加荷重 $P_{w}$ は腰壁の反力による逆向きの水 平変形 $\delta_{T W}$ を打ち消すために必要な水平荷重と見なせ る。目地破壊の進展に伴い $\delta_{T w}$ と $P_{w}$ はともに減少する。 よって, 目地破壊の進展に伴う柱の剛性低下は腰壁によ り拘束される変形が最大になった直後に生じる。また， 剛性低下の程度は, これ以降の $P_{c}$ の増加勾配と $P_{w}$ の 減少勾配の和によって決まる。

3.2 腰壁によって拘束される柱変形

a. 誘導方法

圧縮側腰壁の反力により拘束される柱頭の水平変形 $\delta_{T w}$ を以下の仮定に基づき誘導する。

i）柱にはひび割れ以外の破壊は生じないものとする。

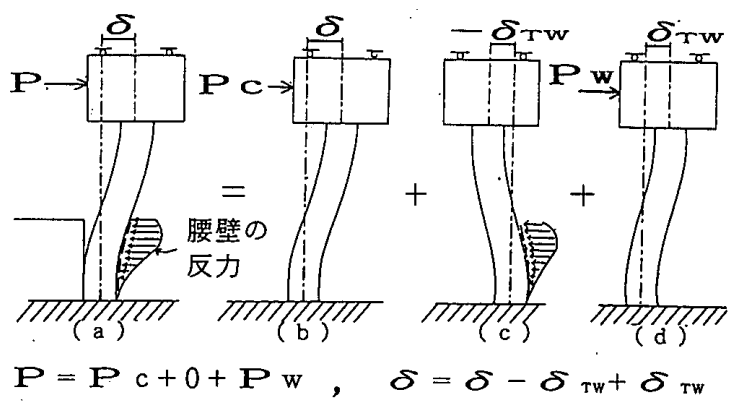

図一10 腰壁付柱の応力・変形および外力の分解 ii）柱の上下端の支持条件については，柱脚は固定端と

し，柱頭は回転のみ完全拘束されているものとする。

iii）柱の変形については，曲げ変形のみ考慮する。

腰壁の反力による変形を求めることと, ii）の仮定よ り柱頭では水平反力が生じないことから, 柱頭から腰壁 上端までの柱部分にはせん断変形は生じない。

iv）腰壁の負担モーメント分布を（2）式とする。これ は, 柱頭の回転拘束が解除された柱に腰壁の反力が作用 したときの柱の曲げモーメント分布に相当する。なお，

（2）式の分布形状の妥当性は，次章で示される。

$$
M_{w}(y)=M_{W B} \cdot\left(1-y / h_{W}\right)^{n}
$$

ここに,

$M_{W B}$ : 柱脚位置の腰壁の負担モーメント

$n$ : モーメント分布形状の次数 $(n>0)$

$y:$ 柱脚を原点とする。 $\left(0 \leqq y \leqq h_{w}\right)$

$h_{w}$ : 腰壁高さ

v）モーメントー曲率関係は付図一 2 に示すように区分 的に線形関係が成立するものとする。付録 2 の重ね合わ せの原理に基づくと, 拘束される変形を算出する際の柱 の剛性は, 図一10(a) の応力状態での柱各部分の瞬間剛 性とすればよい。すなわち，ひび割れが生じていない部 分 $\left(-M_{c} \leqq M \leqq M_{C}\right)$ の剛性は $E I_{1}$ で，ひび割れが生じ る部分 $\left(M<-M_{C}, M_{C}<M\right)$ の剛性は $E I_{2}$ となる。こ のことから，水平荷重の増加が少なく曲げひび割れ状況 が変化しない間では，柱の瞬間曲げ剛性分布は変化しな いことになる。柱の瞬間曲げ剛性は材軸方向により異な るため $E I(y)$ として表す。

b. 最大に拘束される柱変形

柱頭の回転拘束を解除した片持ち柱に（2）式の曲げ モーメントが生じているときの柱頭の水平変形と回転角 を $\delta_{T}, \theta_{T}$, まだその柱の柱頭に単位モーメントが作用し ているときの柱頭の水平変形と回転角を $\bar{\delta}_{T}, \bar{\theta}_{T}$ とする と, $\delta_{T w}$ は，柱頭と柱脚の回転角が等しいときの柱の水 平変位として, 仮想仕事法により（3）式で表せる。

$$
\begin{aligned}
\delta_{T W}= & \delta_{T}-\bar{\delta}_{T} \times\left(\theta_{T} / \bar{\theta}_{T}\right) \\
= & M_{W B}\left\{\int_{h_{W}}^{0} \frac{\left(1-y / h_{W}\right)^{n}}{E I(y)} \cdot(h-y) \cdot d y\right. \\
& \left.-\int_{h}^{0} \frac{h-y}{E I(y)} d y \times \frac{\int_{h_{W}}^{0} \frac{\left(1-y / h_{W}\right)^{n}}{E I(y)} d y}{\int_{h}^{0} \frac{-1}{E I(y)} d y}\right\}
\end{aligned}
$$

（3）式において試験体寸法以外の変数は $M_{W_{B}, E I}$ ( $y), n$ で, 目地破壊の進展に伴いつぎのように変動す る。

$M_{W B}$ は目地破壊の進展に伴って最大に達する(図一5)。 $n$ は単調増加の状態 ${ }^{\sharp 3}$ にあるが， $M_{W B}$ が最大となる前 後ではほぼ一定であるとみなせる（図一9）。EI $(y)$ は, 
$P_{W}$ があまり増加せず柱の水平荷重の増加も小さくなる ため，ほぼ一定であると考えられる(誘導仮定 v)。 $M_{\text {wB }}$ が最大となる前後では, (3) 式の右辺の\}|が 一定となるので $M_{w B}$ が最大となるときに $\delta_{T w}$ が極大に なる。一方， $M_{W B}$ が最大となった以降では， $M_{W B}$ が減少 傾向であることや， $n$ が単調増加するとともに $0 \leqq(1-$ $\left.y / h_{w}\right) \leqq 1$ であるために $\left(1-y / h_{w}\right)^{n}$ が減少することなど を考慮すると， $\delta_{T w}$ が極大になる状態は考えにくい。

よって，M $M_{\text {WB }}$ が最大になるときに $\delta_{T w}$ も最大になる。 すなわち， $M_{w B}$ が最大になるときに腰壁が柱の変形を最 大に拘束することになり, これ以降, 剛性低下が顥著に なる。

3.3 荷重低下と目地強度

荷重低下は, 剛性低下の程度が比較的大きい場合に生 じ， $M_{w B}$ が最大になった直後で $\frac{\partial}{\partial \delta}\left(P_{c}\right)$ と $\frac{\partial}{\partial \delta}\left(P_{w}\right)$ の和 が負になったときに生じる（図一11）。水平荷重 $P$ を分 解する方法として図一100ような分け方もあるが， $P_{w}$ を腰壁の反力で表す方法はつぎの 2 種類ある。

水平荷重と鉛直軸力が作用しているときの柱の反力や 腰壁の反力を図一 2 の記号で表すと, 柱脚位置の水平力 の釣合いや柱脚に関するモーメントの釣合いにより，P は以下の式で表される。ただし，(4.2) 式では $N$ と $\delta$ によるモーメントは無視している。

$$
\begin{aligned}
& P=H_{C B}+H_{W} \\
& P=\left(M_{C r}+M_{C B}\right) / h+M_{W B} / h
\end{aligned}
$$

両式において右辺の第一項は $P_{c}$ を, 第二項は $P_{w}$ を 意味する。ここでは， $M_{W B}$ の挙動之荷重低下の関係を明 らかにする必要があり，(4.2) 式の分け方が適している。

図一 5 に $P_{c}-\delta$ 関係を破線で示す。図中の一は $P_{W}$ $-\delta$ 関係に等しい。 $M_{C B}, M_{C r}$ は付録 1) の算出方法で求 め, $\delta$ は実測値としている。

No.3〜No.8で, $P_{w}$ が最大となった直後に剛性低下 が顕著に生じていることが確認できる。

図一11に $P_{c}, P_{w}-\delta$ 関係の特徵を示す。 $P_{c}-\delta$ 関係 については，柱があまりり破壊しない範囲を対象にする場

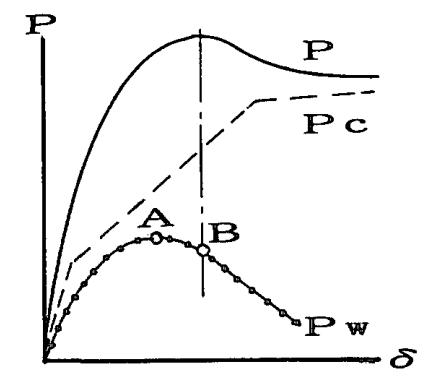

图一11 $P_{c}, P_{w}-\delta$ 関係の特徵

注 3）目地部の破壊にともなって, 腰壁の反力の合力重心も 下端方向に移動する。この時, 腰壁の負担モーメント 分布は $(2)$ 式において $n$ が增加した場合の分布へと 変化する。
表-4 各種強度の実験值

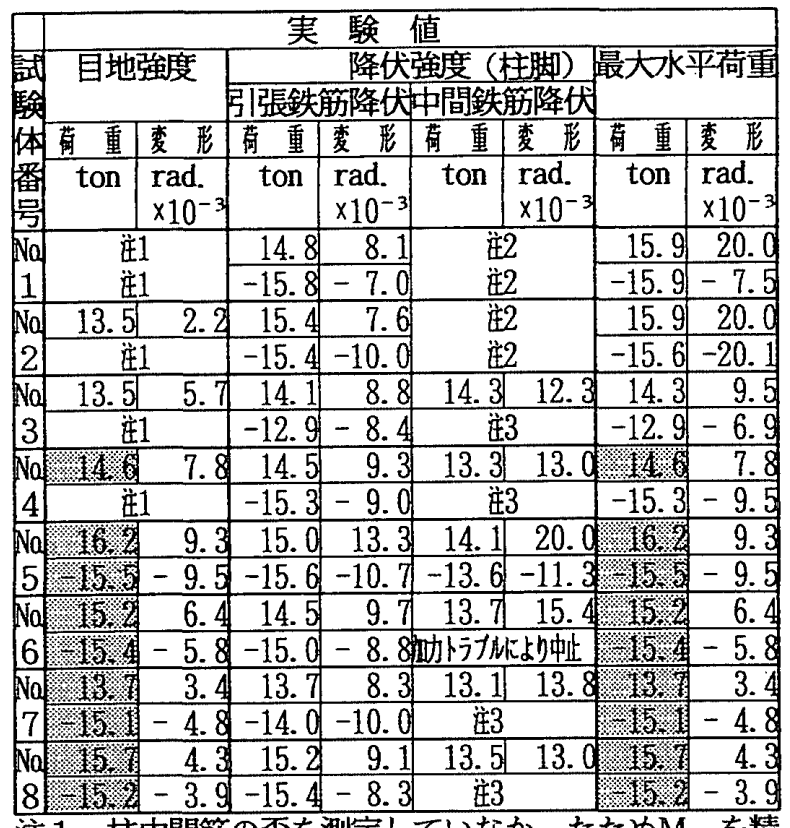

注 1 ; 柱中間筋の歪を測定していなかったためM 度よく評価できなかった。注 2 ; 柱中間筋の歪を测定し なかった。注 $3 ;++2$ サイクルの残留歪みが大きかった。 有: 目地部の破壊に伴って決定した最大荷重

合, $P_{c}$ は $\delta$ の増加に伴ってほぼ単調増加するものと考 えられる。 $P_{w}-\delta$ 関係については, $P_{w}$ は, A 点 $\left(P_{w}\right.$ の最大点）直後では徐々に減少し, B 点以降, 減少勾 配がほぼ一定の状態で減少する。よって, 目地破壊の進 展に伴う荷重低下は, B 点までに生じなければ, 以後, 生じないことになる。そこで, 目地破壊に伴って荷重低 下が生じる可能性があるときの柱の水平せん断力を目地 強度 $Q_{s u v}$ とする。目地強度時は, B点のときとほぼ一 致することになる。目地強度時の腰壁の反力状態は, 柱 脚位置の腰壁の負担モーメント $M_{\mathrm{WB}}$ が最大になった直 後でその诚少勾配がほぼ一定となったときの状態であ る。

図一5においてNo. 5 No. 8 の最大荷重は $M_{\text {wB }} / h$ の 減少勾配がほぼ一定となる時点で生じており，B点と 一致している。No.2については $M_{\mathrm{wB}}$ が不明であるが, 初期に発生している荷重低下時に目地破壊が急激に進展 していることから, 目地強度時に荷重低下が生じたもの と判断できる。No.3については目地強度時に荷重低下 が生じなかったものとして説明できる。本章の定義によ る目地強度の実験値を表一4に示している。柱頭・柱脚 の曲げ降伏以外の破壊が柱に生じなければ, 最大荷重は 目地強度と降伏強度のうち大きい強度に等しいことが確 認できる。

\section{4. 腰壁の終局モーメント分布と目地部の終局ひずみ比} 目地強度時の圧縮側腰壁の負担モーメント分布を腰壁 の終局モーメント分布とする。この分布を $m\left(={ }_{s L} \sigma_{B}\right.$. 


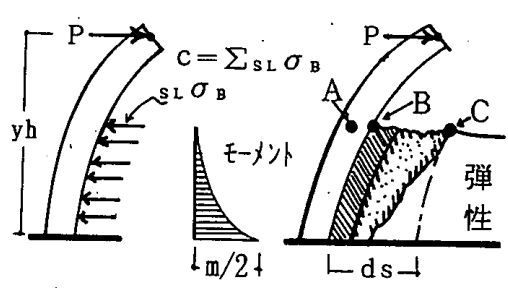

(a)

(b)

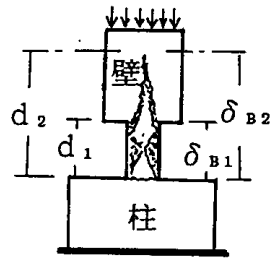

(c)

$$
\mathrm{m}_{\mathrm{WB}}=\mathrm{M}_{\mathrm{wB}} / \mathrm{m}, \quad \xi_{\mathrm{sL}}=\delta_{\mathrm{sL}} / \mathrm{ds}_{\mathrm{s}}{ }_{\mathrm{sL}} \varepsilon_{\mathrm{B}}\left(=\delta_{\mathrm{sL}} / \delta_{\mathrm{B}}\right)
$$

$\mathrm{c}={ }_{\mathrm{sL}} \sigma_{\mathrm{B}} \cdot \mathrm{ts} \cdot \mathrm{hm}, \quad \mathrm{m}=\mathrm{sL} \sigma_{\mathrm{B}} \cdot \mathrm{ts} \cdot \mathrm{h} \mathrm{w}{ }^{2}(=2 \cdot \mathrm{c} \cdot \mathrm{hm} / 2)$

$\delta_{\mathrm{cw}} ;(\mathrm{b})$ の 点の柱水平変位, $\delta_{\mathrm{w}}$; (b)の $\mathrm{C}$ 点の水平变位

$\delta \mathrm{sL} ;(\mathrm{b})$ の B - C 点間の水平压縮变形

$\mathrm{ds}$; 壁の水平方向の破壊区間、目地部のみが破壊する場合は (c)の $\mathrm{d}_{1}$ で、壁に破壊が広がる場合は $\mathrm{d}_{2}$ とする。

$s L \mathcal{E}_{\mathrm{B}}$; (c)の最大圧缩強度時の王縮変形 $\delta_{\mathrm{B}}$ をdsで除した破壊歪

图一12 4 章で用いる記号

$\left.t_{s} \cdot h_{w}^{2}\right)$ で除した分布を $m_{s L u}(y)$ とし, 柱脚位置の值 を $m_{s L U}$ とする。本章では, 目地強度時までは柱の破壊 による急激な剛性低下は生じないものとし，また目地部 の圧縮特性も一種類として論を展開する。図一12 に本 章で用いる記号を示す。

\section{$4.1 m_{W_{B}}-\xi_{S L}$ 関係と目地強度}

前章では $M_{w B}-\delta$ (柱頭の水平変位) 関係で目地強度 を定義したが, $\delta$ が柱頭から腰壁上端までの区間（開口 区間）で生ずる柱変形と,腰壁上端から柱脚までの区間 で生ずる柱変形からなるため， $\delta$ の変化傾向は，開口区 間の柱の長さや応力状態によって異なる。本章では, 腰 壁上端位置の柱の水平変形と密接に関係する圧縮側腰壁 の目地部水平変形 $\delta_{s L}$ で, 目地強度時を判断することとに する。図一13に実験による $m_{w B}-\xi_{S L}$ 関係を示す。これ は $M_{W B}-\delta_{S L}$ 関係を無次元量で表している。同関係で判 断される目地強度時と最大荷重時は一致している。

\section{2 終局モーメント分布のパラメータ}

$m_{S L U}(y)$ は，目地部のひずみ分布が既知であると， 目地部の圧縮特性を仮定することにより算出できる。 2.3 節で述べたように目地強度前後の目地部のひずみ分 布形状は徐々に変化し，ほぼ一定の形状であると見なせ る。すると， $m_{s L v}(y)$ は目地部のひずみ分布形状と圧 縮特性から算出される結果で推定できる。ここでは, 目

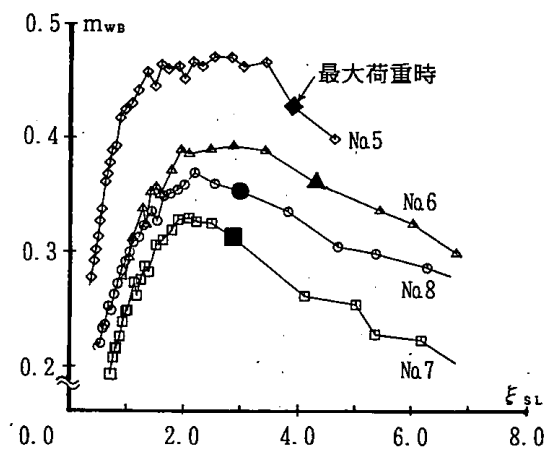

図一13 $m_{w B}-\xi_{S L}$ 関係と最大荷重時
地部の圧縮特性を一種類としているため, $m_{s L U}(y)$ は 主に目地部のひずみ分布形状の影響を受ける。このひず み分布形状は，柱の変位と目地部で生じる変形の関係 （2.3 節）から, 腰壁と接する柱の境界の柱変位分布形 状と密接に関係する。

柱の変位は, 柱の曲げモーメント分布が既知であると, 柱断面の剛性を仮定することにより算出できる。ここで は，柱は破壊しない範囲を対象にしているため，柱の変 位分布形状は主に柱の曲げモーメント分布形状に影響を 受けることになる（2.3 節）。図一9に示したように $m_{s L v}(y)$ の分布形状は目地強度前後ではほぼ一定の形 状であるから，目地強度時の柱の変位分布形状は，モ一 メント分布形状を表す $h_{w} / y h, Q_{s L v^{*}} y h / m_{S L U^{*}} \cdot m$ に主 に影響を受けることになる。よって， $m_{s L v}(y)$ は (5.1) 式のように関数記号で表せる。この右辺の $m_{S L U}$ は $m_{s L v}(y)$ に関係する項であるから，(5.1）式は (5.2) 式のように表せる。すなわち， $m_{S L U}(y)$ に影響を与え る主なパラメータは $h_{w} / y h, Q_{s L v} \cdot y h / m$ となる。

$$
\begin{aligned}
& m_{S L U}(y)=F\left(h_{w} / y h, Q_{s L U^{*}} y h / m_{S L U^{*}} m\right) \\
& m_{s L v}(y)=G\left(h_{w} / y h, Q_{s L U^{*}} y h / m\right) \cdots \cdots \cdots
\end{aligned}
$$

\section{3 目地部の終局ひずみ比とパラメータ}

腰壁の破壊は, 実験では目地部に限定されていたが, 目地の形状・寸法によっては目地部以外の壁部分にも広 がる（図一12(b)，(c)）。この破壊する範囲の壁部分も 目地部に含めて, 破壊する目地部之破壊しない壁部分(弾 性の壁）に腰壁を分けると，柱の水平変位 $\delta_{C W}$ は腰壁上 端位置の, $\delta_{S L}$ と壁の弾性水平変位 $\delta_{w}$ の和で推定でき る。

目地強度時の $\xi_{S L}$ を $\xi_{S L U}$ とすると，このときの $\delta_{S L}$ は $\xi_{S L U \cdot S L} \varepsilon_{B} \cdot d_{s}$ で表せる。本論では， $\xi_{S L U}$ を目地部の終局 ひずみ比とする。 $\xi_{s L v}$ は (5.1) 式の $m_{S L v}(y)$ と同様に, $h_{w} / y h, Q_{S L U} \cdot y h / m_{S L U} \cdot m$ の影響を受けることになる が, $m_{s L v}(y)$ が (5.2) 式で表されるので $h_{w} / y h, Q_{s L U}$ $\cdot y h / m$ が主なパラメータとなる。

\section{4 有限要素法解析}

a. 解析目的

$m_{S L U}(y)$ または $\xi_{s L U}$ と $h_{w} / y h, Q_{s L U^{*}} y h / m$ の関係を 明らかにする。

\section{b. 解析仮定}

解析には弾・塑性有限要素法解析プログラムを使用す る。プログラムの検証と諸仮定については文献 6）で述 べてあるので，以下には仮定の特徴を記す。

解析は平面応力問題とした。コンクリートの要素は 8 節点アイソパラメトリック平面要素で要素内積分点を 9 点とし、コンクリートのひび割れは要素全体に分散させ る方法でモデル化した。鉄筋要素は線材要素とし，柱の 主筋と帯筋のみを試験体の鉄筋量に合わせて解析モデル に配置した。コンクリートと鉄筋の相互作用については, 


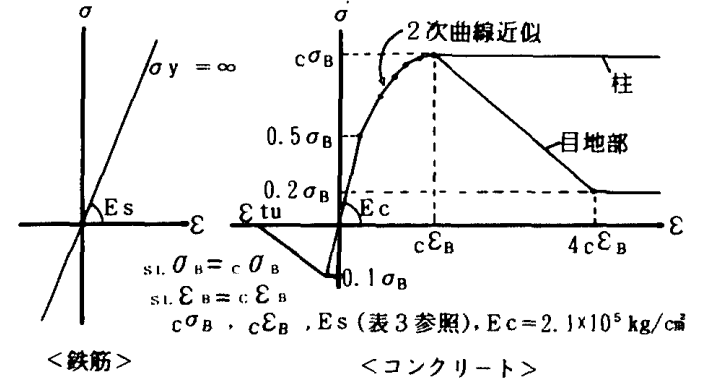

図一14 仮定した材料特性

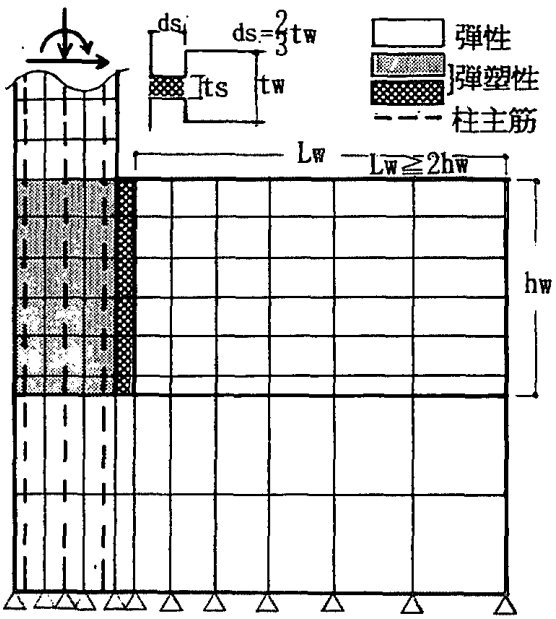

図一15 解析モデルと要素分割

ひび割れ発生以降のコンクリートの引張剛性効果のみで 考慮した。

図一14に実験值を参考にして仮定した材料特性を示 す。目地強度時までに柱には，ひび割れ以外の破壊は生 じないことを前提にしていることから，柱の主筋と带筋 は降伏しないものとした。

c、解析モデルと加力

図一15に解析モデルと要素分割の一例を示す。解析 モデルについては，柱と基礎梁および王縮側腰壁からな る形状とした。柱と基礎梁の断面および壁厚の寸法は試 験体と同じ値とし, 目地部の幅 $\left(d_{s}\right.$ に等しい) は壁厚 $\left(t_{w}\right)$ の $2 / 3$ とした。柱の反曲点位置については, 目地部のひ
表一5 解析モデルの種類と寸法

\begin{tabular}{|l|l|l|l|l|l|l|l|}
\hline $\mathrm{h} w / \mathrm{yb}$ & \multicolumn{7}{|c|}{$1,0.5 .0$} \\
\hline $\mathrm{h}$ (c⿴囗十) & 25 & 35 & 45 & 55 & 65 & 75 & 85 \\
\hline & 3.5 & 1.5 & 1.5 & 2.6 & 3.5 & 3.5 & 3.5 \\
& & 2.0 & 2.5 & 3.5 & 3.5 & 4.5 & 4.5 \\
$\mathrm{ts}(\mathrm{cm})$ & & 2.5 & 3.5 & & & & \\
& & 3.0 & & & & & \\
& & 3.5 & & & & & \\
\hline
\end{tabular}

ずみ分布形状と同様に目地強度前後ではあまり変化しな いものと考えて，一定とした。

解析については， $h_{w}$ と $t_{s}$ の寸法を表一5 のようにし， それぞれの組み合わせに対し $h_{w} / y h$ を $1,0.5,003$ 種類とし， 51 case 行った。

加力については, 柱軸力を一定 $(N=25$ ton $)$ とし， 目地破壊に伴い荷重低下が生じる場合があるので，水平 力の制御は反曲点の水平変位を増分させる方法（変位増 分法）によって行った。なお， $h_{w} / y h=0$ の加力は柱頭 にモーメントを加えた。

\section{5 解析結果}

a. $m_{\mathrm{WB}}, H_{w} / c, P / c, M t / m-\xi_{s L}$ 関係

図一16に解析による $m_{W B}, H_{w} / c, P / c, M t / m-\xi_{S L}$ の関係を 2 シリーズについて示す。シリーズIでは $h_{w} / y h=1,0.5,0$ の結果を, シリーズ II では $h_{w} / y h$ =1の結果をそれぞれ示している。図中の○は目地強度 時で，この $m_{S L U}$ は $m_{W B}$ の最大值に対し $3 \sim 5 \%$ 小さく なる程度であった。

目地破壊によって最大荷重が決定したシリーズI-a では, 目地強度時と最大荷重時が一致している。

目地強度は， $h_{w} / y h$ の娍少に伴って小さくなり， $h_{w} / y h=0$ では零となる。すなわち, 目地強度は腰壁上 端位置の柱の作用せん断力と作用モーメントの割合に よって変化し, 特にモーメントだけが作用する場合でも 目地破壊が進展し，目地強度に達することになる。

腰壁の水平反力 $\left(H_{w} / c\right)$ の最大值とそのときの水平 荷重 $(P / \mathrm{c})$ の値を比較すると, 両者にはかなり差が 生じる場合が多く，序で述べた平石らの仮定と異なって いる。

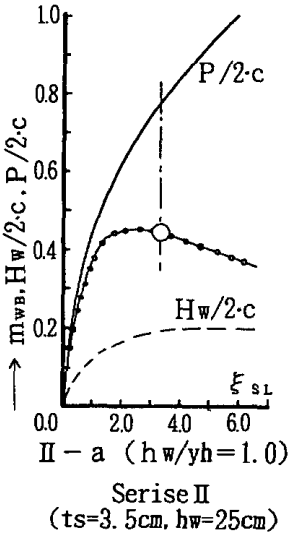

b. $m_{s L v}(y)-h_{w} / y h, Q_{s L U} \cdot y h /$ $m$ の関係式

図一17に解析による $m_{S L U}-$ $h_{w} / y h, Q_{S L U} \cdot y h / m$ の関係を示 す。解析結果は, 縦軸の值を $m_{\text {SLU, }}$ 横軸の値を $Q_{S L U} \cdot y h / m$ とし， $h_{w} / y h$ 種類ごとに白塗の記号 で示している。解析では $h_{w}, y h$, $t_{s}$ の絶対值を変化させているに もかかわらず, $m_{s L v}$ は $h_{w} / y h$ の 種類ごとに， $Q_{s L U} \cdot y h / m$ に伴っ て連続的に变化しており, $h_{w} / y h$ と $Q_{s L V} \cdot y h / m$ を $m_{s L U}$ の 


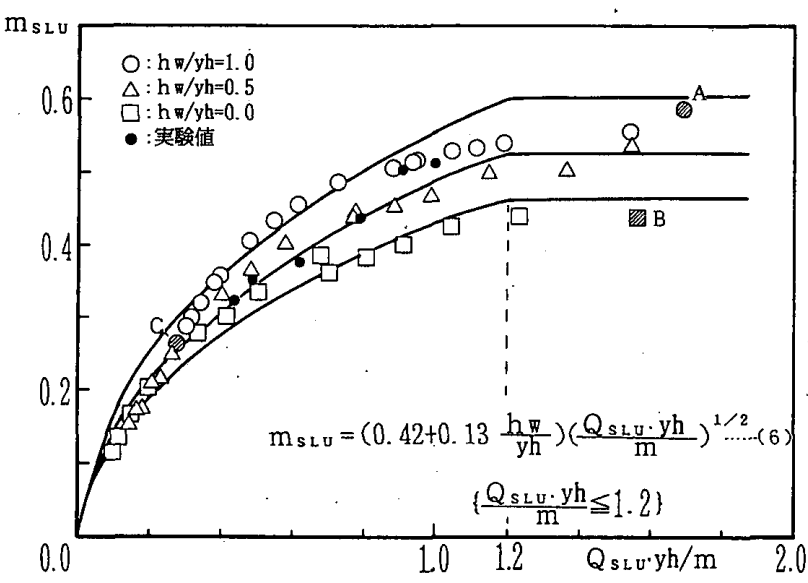

図-17 $m_{s L U}-h_{w} / y h, Q_{s L v} \cdot y h / m$ 関係

主パラメータとしてよいことが確認できる。

$m_{S L U}$ は $Q_{s L v} \cdot y h / m=1 \sim 1.5$ より大きい範囲では $h_{w} / y h$ の種類ごとに一定値に収束する傾向を示してい る。この傾向は, $Q_{s L v^{*}} y h / m$ が大きくなると, 柱の曲 げモーメントに対する腰壁の終局モーメントの割合も小 さくなり, 目地部のひずみ分布形状に関係する柱のモ一 メント分布形状が, $Q_{s L v^{*}} \cdot y h / m$ の影響を受けにくくな るためと考えられる。図中の実線は解析値について求め た近似式（図中の（6）式）によるもので， $Q_{s L v} \cdot y h$ $/ m \geqq 1.2 て ゙ Q_{s L v} \cdot y h / m$ に影響を受けないものとして 一定としている。は実験值で, 表一6に実験値と（6) 式による計算値を比較して示す。両者はよい対応を示し ている。

図一18に解析による代表的な終局モーメント分布の 形状を破線で，実験結果を白塗の記号でそれぞれ示す。 解析の分布は図一 17 中の $\mathrm{A}, \mathrm{B}, \mathrm{C}$ の分布の形状で, $h_{w} / y h$ と $Q_{S L U^{*}} \cdot y h /_{m}$ の值によって若干異なるが, 実験

表一 $m_{s L v} \cdot \xi_{S L U}$ の実験値之計算値

\begin{tabular}{|c|c|c|c|c|c|c|}
\hline 試験体番号 & No. 3 & No. 4 & No. 5 & No. 6 & No. 7 & No. 8 \\
\hline $\mathrm{Q}_{\mathrm{sLu}} \cdot \mathrm{yh} / \mathrm{n}$ & 0.99 & 0.90 & 0.78 & 0.62 & 0.44 & 0.49 \\
\hline $\mathrm{hw} / \mathrm{yh}$ & 0.63 & 0.58 & 0.5 & 0.75 & 0.90 & 0.83 \\
\hline $\mathrm{m}_{\mathrm{SLU}}$ 実験 & 0.51 & 0.50 & 0.43 & 0.37 & 0.32 & 0.35 \\
\hline 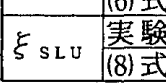 & $\begin{array}{r}0.30 \\
4.0 \\
3.9 \\
\end{array}$ & $\begin{array}{r}0.47 \\
4.0 \\
4.1\end{array}$ & $\begin{array}{r}0.44 \\
4.3 \\
4.4\end{array}$ & $\begin{array}{r}0.41 \\
4.5 \\
4.5\end{array}$ & $\begin{array}{r}0.36 \\
4.0 \\
4.6\end{array}$ & $\begin{array}{r}0.31 \\
5.1 \\
4.6\end{array}$ \\
\hline
\end{tabular}

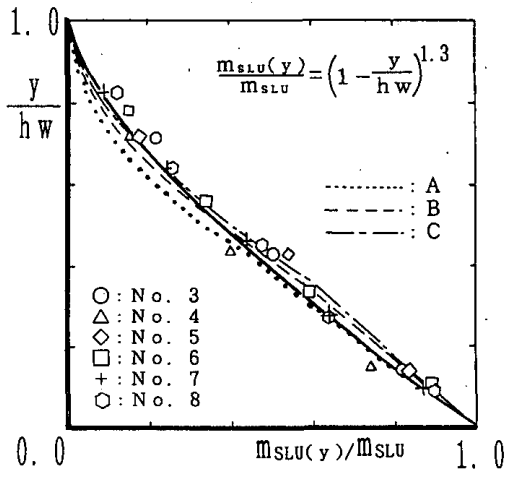

図一18 $m_{s L v}(y)$ の分布形状

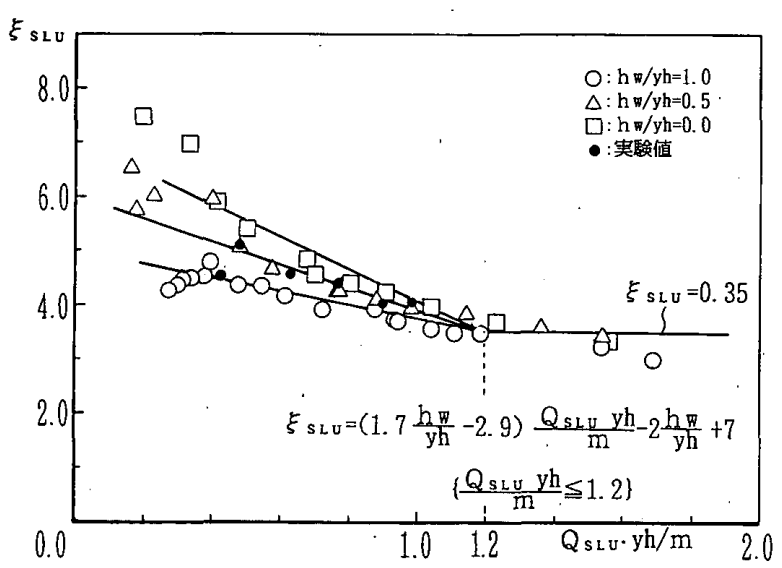

図一19 $\xi_{s L U}-h_{w} / y h, Q_{s L U^{*}} y h / m$ 関係

の分布について求めた図中の近似式（実線）に近くなっ ている。よって, $m_{S L U}(y)$ はつぎのように表される。

$$
m_{S L U}(y)=m_{S L U}\left(1-\frac{y}{h_{W}}\right)^{1.3}
$$

ここに，

$$
m_{S L U}=\left(0.43+0.12 \frac{h_{W}}{y h}\right) \sqrt{\frac{Q_{s L U^{*}} y h}{s_{L} \sigma_{B} \cdot t_{s} \cdot h_{W}^{2}}}
$$

c. $\xi_{S L U}-h_{w} / y h, Q_{s L U} \cdot y h / m$ の関係式

図一19に解析による $\xi_{s L v}-h_{w} / y h, Q_{s L U} \cdot y h / m$ の関 係を示す。縦軸の值を $\xi_{S L U}$ とし図一17 と同様に示して いる。図中の実線は $Q_{S L U} \cdot y h / m \leqq 1.2$ で解析値につい て求めた近似式（図中の式）によるもので， $Q_{s L U} \cdot y h$ $/ m \geqq 1.2$ では一定としている。は実験值で, 表一6 に実験值と計算値を比較して示す。両者はよい対応を示 している。以下に $\xi_{s L v}$ の式を示す。

$$
\xi_{S L U}=\left(1.7 \frac{h_{w}}{y h}-2.9\right) \frac{Q_{s L U} \cdot y h}{s_{L} \sigma_{B} \cdot t_{S} \cdot h_{w}^{2}}-2 \frac{h_{w}}{y h}+7
$$

\section{5.まとめ}

構造目地を有する腰壁付き柱が水平荷重を受ける場合 の，目地破壊に起因する最大荷重の決定過程と腰壁の反 力挙動について検討した。その結果を以下にまとめる。

（1）腰壁が柱脚位置で負担するモーメント $M_{W B}$ 一腰壁 上端位置の目地部の水平変形 $\delta_{S L}$ の関係において, $M_{W B}$ が最大点を過ぎその減少勾配がほぼ一定となったとき に, 柱の荷重-変形関係で目地破壊に伴う荷重低下が生 じうる。このときの柱の水平せん断力を目地強度と定義 した。

（2）柱の最大水平荷重は, 目地強度と降伏強度のうち 大きい強度に等しいことを確認した。

（3）目地強度時の，腰壁の終局モーメント分布または 目地部の終局ひずみ比と柱の水平荷重の関係を,それぞ れ（7）式（8）式で示した。 


\section{謝 辞}

本論文をまとめる際に，九州芸術工科大学・大久保全 陸教授に根切丁寧なご助言を頂きました。また，同大学 学部生・鈴木就生君, 浦本洋一郎君には図面作成を協力 して頂きました。ここに謝意を表します。

\section{参考文献}

1）日本建築学会：1968 年十勝沖地震災害調查報告なざ

2）大久保全陸, 塩屋晋一：構造目地を有する鉄筋コンクリー 卜造腰壁付き骨組の力学的特性に関する研究・そのI-腰 壁付き梁・柱十字形骨組の加力実験について，日本建築 学会構造系論文報告集, No. 380, pp. 10 21, 昭和 62 年 10 月

3）塩屋晋一：構造目地を有する鉄筋コンクリート造腰壁付 き骨組の力学的特性に関する研究・その II-腰壁付き梁の 力学的特性と曲げ強度評価式, 日本建築学会構造系論文 報告集, No. 416, pp. 91 104, 1990 年 10 月

4）塩屋晋一，藤村雅彦ほか：構造目地を有する腰壁付き柱 の力学的特性に関する実験的研究（その $1,2 ， 3$ ）, 日本 建築学会九州支部研究報告集, pp. 293 304, 1991 年 3 月

5）平石久廣, 川島俊一, 佐藤彰芳 : 鉄筋コンクリート造腰 壁付き柱に設けたスリットの効果に関する研究，日本建 築学会構造系論文報告集, No. 326, pp. 83 92, 昭和 61 年 4 月

6) 大久保全陸, 瀧瀬 潤：曲げ降伏後の梁伸び現象が梁降 伏形 R/C 骨組の変形挙動に及ぼす影響, 日本建築学会九 州支部研究報告集, pp. 265 - 268，1992 年 3 月

\section{付録 1 柱の曲げモーメントの算出方法}

付図一1にモーメントを受ける柱断面の忘力状態とひすみ分 布および記号を示す。鉄筋の引張力 $T_{s}, T_{s}^{\prime}$, 圧縮力 $C_{s}$ につい ては，測定される柱主筋のひずみと鉄筋の応力・ひずみ関係か ら算出する。コンクリートの圧維応力の重心位置 $G_{c}$ について は，鉄筋のひずみで直線補間される曲げ圧縮域のひずみ分布と コンクリートの応カ・ひずみ関係から算出する。そして, 腰壁 と接する範囲の柱の断面軸力については，壁の影響を無視し， 作用軸力 $N$ とする。曲げモーメントは， $G_{c}$ に関するこれら断 面内力のモーメントの和として算出する。応力・ひずみ関係に ついては，材料試験結果を基に，鉄筋をバイリニアー型，コン クリートを梅村博士の $e$ 関数之仮定する。コンクリートの引張 応力については無視する。

\section{付録 2 瞬間剛性に基つく重ね合わせの原理}

一般に柱の曲げモーメント-曲率関係 $(M-\phi)$ やんん断力ー せん断ひずみの関係は，折れ線で近似され，非弾性範囲でも区

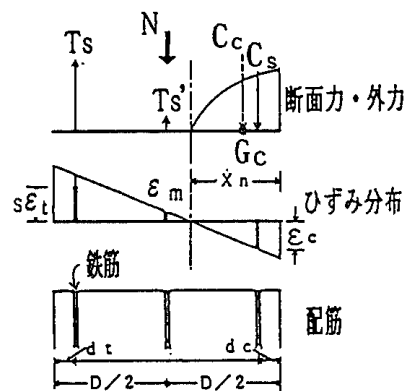

付図一1 柱断面の応力とひずみおよび記号
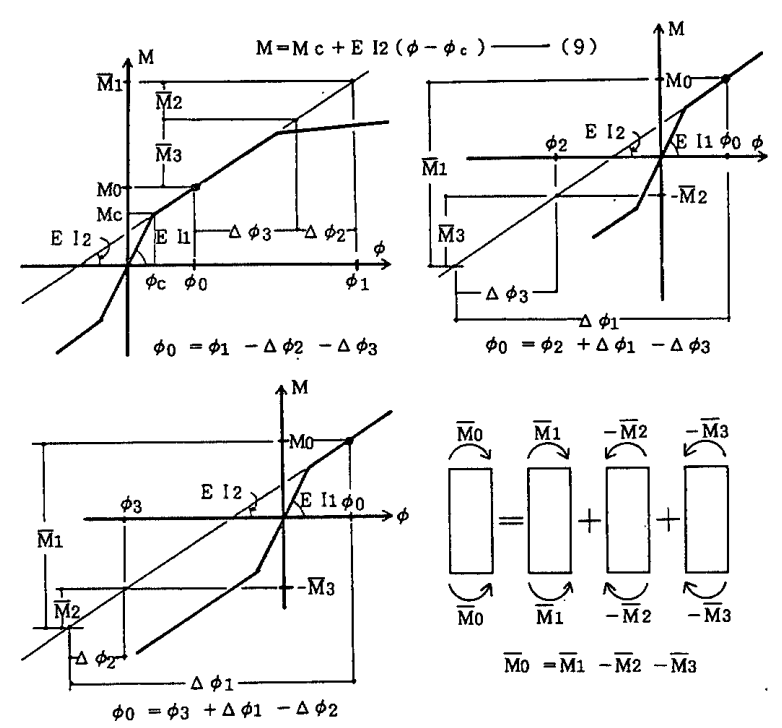

付図一2 柱の応力・変形の分解

分的に線形関係が仮定される。弾性範囲で用いられる線形関係 に基つくく重站わせの原理は，非弾性範用で付図一2のように 修正適用できる。すなわち， $M_{0}$ が作用しているときの柱の応力・ 変形は, 任意に分解される作用力による応力・変形のうち, あ る作用力による応力・変形を $M$ - $\phi$ 関係で $M_{0}$ が対応する区分 の $M-\phi$ 関係式 ( ( 9 ) 式)により, その他の作用力による応力 変形をその区分の瞬間剛性 $\left(E I_{2}\right)$ によりそれそれれ求め,これら の応力・変形を加算したものに等しいことになる。本文中の図 -10 の場合, $\delta$ は㬰際に生じる変形で， $\delta_{T w}$ は生じない変形な ので, 付図一 2 において $M_{0}=\bar{M}_{1}, \bar{M}_{2}=-\bar{M}_{3}$ とし $\bar{M}_{1}$ による変 形を(9) 式で求めると $\phi_{0}=\phi_{1}$ となるのと同様に, 図一10の (c) (d) の柱の各高さ位置の㴊性は, 同図（a）の柱の各高さ位置の 瞬間剛性と考えればよい。

(1992 年 3 月 10 日原稿受理, 1992 年 8 月 4 日採用決定) 